[Chem. Pharm. Bull.

35( 1) 97-107 (1987)

\title{
New Acylated Flavonol Glucosides in Allium tuberosum RoTTLER
}

\author{
Takatoshi Yoshida, * TaKashi Saito, and Shizuo Kadoya \\ Research Institute, Daiichi Seiyaku Co., Ltd., 16-13, Kitakasai \\ l-chome, Edogawa-ku, Tokyo 134, Japan
}

(Received June 12, 1986)

Six flavonoids ( $1-\mathbf{6})$ were isolated from the leaves of Allium tuberosum RotTLER (Liliaceae). Their structures were characterized as 3- $O-\beta$-sophorosyl-7- $O-\beta$-D-(2-O-feruloyl)glucosylkaempferol (1), 3,4'-di- $O$ - $\beta$-D-glucosyl-7- $O-\beta$-D-(2- $O$-feruloyl)glucosylkaempferol (2), 3- $O$ - $\beta$-D-(2- $O$-feruloyl)glucosyl-7,4'-di- $O$ - $\beta$-D-glucosylkaempferol (3), 3,4'-di- $O$ - $\beta$-D-glucosylkaempferol (4), 3,4' - di- $O$ - $\beta$ D-glucosylquercetin (5) and 3-O- $\beta$-sophorosylkaempferol $(\mathbf{6})$ by examination of their physicochemical properties. On partial acid hydrolysis, 1 gave $7-O-\beta-\mathrm{D}-(2-O$-feruloyl $)$ glucosylkaempferol (10), and on enzymatic hydrolysis, 1 and 3 afforded $3-O-\beta$-D-glucosyl-7- $O-\beta$-D-(2-O-feruloyl)glucosylkaempferol (11) and 3-O- $\beta$-D-(2-O-feruloyl)glucosylkaempferol (14), respectively. At $\mathrm{pH}$ 7.0 or at $\mathrm{pH} 11.0$, or both, the $2-O$-feruloyl group of $\mathbf{1}, \mathbf{2}, \mathbf{1 0}$ and 11 migrated to give the corresponding 6- $O$-feruloyl derivatives $(15,17,16$ and 18). Compounds $1-3$ and their derivatives $10,11,14,15,16,17$ and 18 are new acylated flavonol glucosides.

Keywords - Allium tuberosum; Liliaceae; flavonol; kaempferol; quercetin; ferulic acid; glucoside; acylated flavonol glucoside; acyl migration

Allium tuberosum ROTTLER (Liliaceae) is a perennial herb which has been cultivated widely and whose leaves have been used as food. Various sulfide derivatives, ${ }^{1)}$ linalool ${ }^{1)}$ and 3$O$-rhamnogalactosyl-7-O-rhamnosylkaempferol ${ }^{2)}$ have been isolated from the leaves of $A$. tuberosum. According to the dictionary of Chinese drugs, ${ }^{3)}$ they have been used for treatment of abdominal pain, diarrhea, hematemesis, snake-bite and asthma. We have attempted to

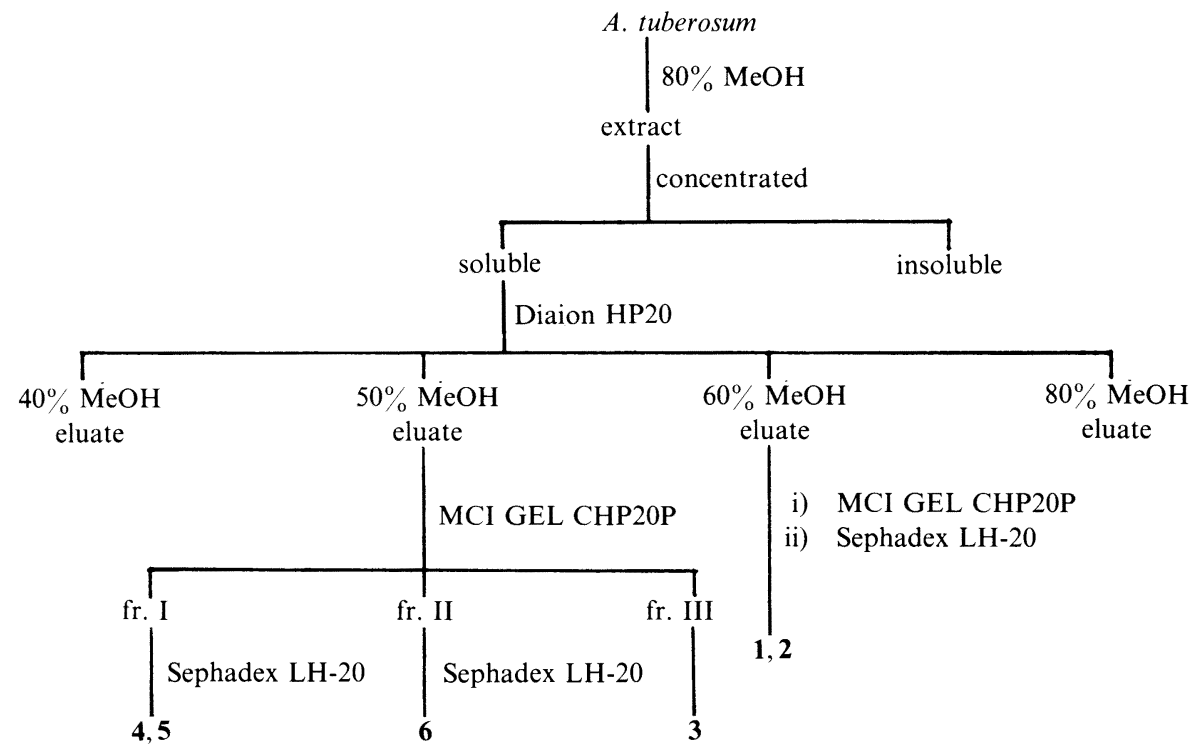

Chart 1 
isolate anti-allergic agents from A. tuberosum, and have obtained three new acylated flavonol glucosides together with three known flavonol glucosides. This paper deals with the isolation and structural elucidation of these compounds, and the acyl migration of acylated flavonol glucosides.

Commercially available fresh leaves of $A$. tuberosum were extracted with $80 \%$ methanol, and the extract was treated as shown in Chart 1 to isolate compounds $1-6$.

Compound 1 exhibited absorption maxima at 233, 269 and $333 \mathrm{~nm}$ in the ultraviolet (UV) spectrum, and its field desorption mass spectrum (FD-MS) showed [ $\mathrm{M}^{+}+\mathrm{K}$ ] at $m / z 987$ and $\left[\mathrm{M}^{+}+\mathrm{Na}\right]$ at $m / z$ 971. On acid hydrolysis, 1 gave kaempferol and D-glucose, and on alkaline hydrolysis it afforded ferulic acid and kaempferol glucoside (8). Methylation of 1 according to Hakomori's method ${ }^{4)}$ followed by hydrolysis gave, in a ratio of $2: 1,2,3,4,6-$ tetra- $O$-methylglucose and 3,4,6-tri- $O$-methylglucose, which were identified as alditol acetates by gas liquid chromatography (GLC) and GLC-mass spectrometry (GLC-MS). Acetylation of $\mathbf{1}$ afforded a tridecaacetate, the proton nuclear magnetic resonance $\left({ }^{1} \mathrm{H}-\mathrm{NMR}\right)$ spectrum of which showed the signals of three aromatic and ten aliphatic acetoxyl protons. From these data 1 was found to contain a D-glucosyl $(1 \rightarrow 2)$-D-glucose moiety and a D-glucose moiety attached to kaempferol, and a feruloyl moiety attached to D-glucose.

In the UV spectrum the diagnostic shifts ${ }^{5)}$ of $\mathbf{8}$ on addition of sodium acetate, sodium methoxide or aluminum chloride showed that glucose was linked to kaempferol at C-3 and -7. $\left.{ }^{6}\right)$ The ${ }^{1} \mathrm{H}-\mathrm{NMR}$ spectrum of $\mathbf{8}$, as shown in Table $\mathrm{I}$, exhibited the signals of $\beta$-anomeric protons at $4.66,5.10$ and $5.72 \mathrm{ppm}$, which could be assigned to the anomeric protons of glucose linked to C-2 of glucose, and to C-3 and -7 of kaempferol, respectively. In the ${ }^{13} \mathrm{C}$ nuclear magnetic resonance $\left({ }^{13} \mathrm{C}-\mathrm{NMR}\right)$ spectrum, as shown in Table II, the signals due to $\mathrm{C}$ 3 and -7 were shifted upfield, and the signals due to C-2, $-4,-6,-8$ and -10 were shifted downfield from those of kaempferol. ${ }^{7)}$ On partial acid hydrolysis with $1 \%$ sulfuric acid, 8 gave 7-O- $\beta$-D-glucosylkaempferol (9) and sophorose. ${ }^{8 a, b)}$ On enzymatic hydrolysis with $\beta$-glucosidase, 8 afforded 3-O- $\beta$-sophorosylkaempferol $(6){ }^{8 a, b)}$ These results suggested that 8 is $3-O$ $\beta$-sophorosyl-7-O- $\beta$-D-glucosylkaempferol. ${ }^{8 b}$ )

The linkage between the feruloyl group and glucose in $\mathbf{1}$ was determined from the ${ }^{1} \mathrm{H}$ -

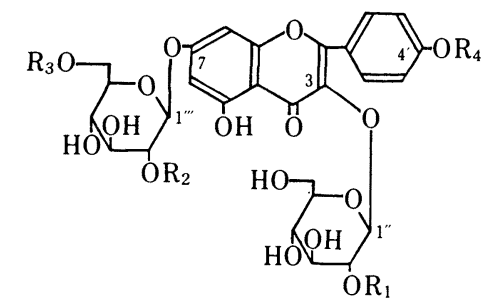

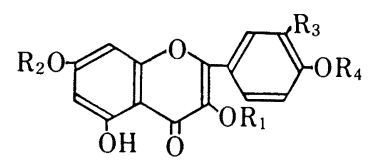

$\begin{array}{rccccr} & \mathrm{R}_{1} & \mathrm{R}_{2} & \mathrm{R}_{3} & \mathrm{R}_{4} & \\ \mathbf{1} & - \text { Glc } & -\mathrm{Fer} & -\mathrm{H} & -\mathrm{H} & \mathbf{4} \\ \mathbf{2} & -\mathrm{H} & -\mathrm{Fer} & -\mathrm{H} & -\mathrm{Glc} & \mathbf{5} \\ \mathbf{3} & - \text { Fer } & -\mathrm{H} & -\mathrm{H} & -\mathrm{Glc} & \mathbf{6} \\ \mathbf{8} & - \text { Glc } & -\mathrm{H} & -\mathrm{H} & -\mathrm{H} & \mathbf{7} \\ \mathbf{1 1} & -\mathrm{H} & -\mathrm{Fer} & -\mathrm{H} & -\mathrm{H} & \mathbf{9} \\ \mathbf{1 2} & -\mathrm{H} & -\mathrm{H} & -\mathrm{H} & -\mathrm{H} & \mathbf{1 0} \\ \mathbf{1 3} & -\mathrm{H} & -\mathrm{H} & -\mathrm{H} & -\mathrm{Glc} & \mathbf{1 4} \\ \mathbf{1 5} & - \text { Glc } & -\mathrm{H} & - \text { Fer } & -\mathrm{H} & \mathbf{1 6} \\ \mathbf{1 7} & -\mathrm{H} & -\mathrm{H} & -\mathrm{Fer} & -\mathrm{Glc} & \\ \mathbf{1 8} & -\mathrm{H} & -\mathrm{H} & - \text { Fer } & -\mathrm{H} & \end{array}$

$$
\begin{aligned}
& \begin{array}{llll}
\mathrm{R}_{1} & \mathrm{R}_{2} & \mathrm{R}_{3} & \mathrm{R}_{4}
\end{array} \\
& \begin{array}{llll}
-\mathrm{Glc} & -\mathrm{H} & -\mathrm{H} & -\mathrm{Glc}
\end{array} \\
& \begin{array}{llll}
-\mathrm{Glc} & -\mathrm{H} & -\mathrm{OH} & -\mathrm{Glc}
\end{array} \\
& -\mathrm{Glc}^{2}-\mathrm{Glc} \quad-\mathrm{H} \quad-\mathrm{H} \quad-\mathrm{H} \\
& \begin{array}{llll}
-\mathrm{H} & -\mathrm{H} & -\mathrm{H} & -\mathrm{H}
\end{array} \\
& \begin{array}{llll}
-\mathrm{H} & -\mathrm{Glc} & -\mathrm{H} & -\mathrm{H}
\end{array} \\
& -\mathrm{H}-\mathrm{Glc}^{2}-\mathrm{Fer} \quad-\mathrm{H} \quad-\mathrm{H} \\
& \begin{array}{llll}
-\mathrm{Glc}^{2}-\mathrm{Fer} & -\mathrm{H} & -\mathrm{H} & -\mathrm{H}
\end{array} \\
& -\mathrm{H}-\mathrm{Glc}-\mathrm{Fer} \quad-\mathrm{H} \quad-\mathrm{H} \\
& \text { Glc: } \beta \text {-D-glucosyl } \\
& \text { Fer: }
\end{aligned}
$$

Chart 2 


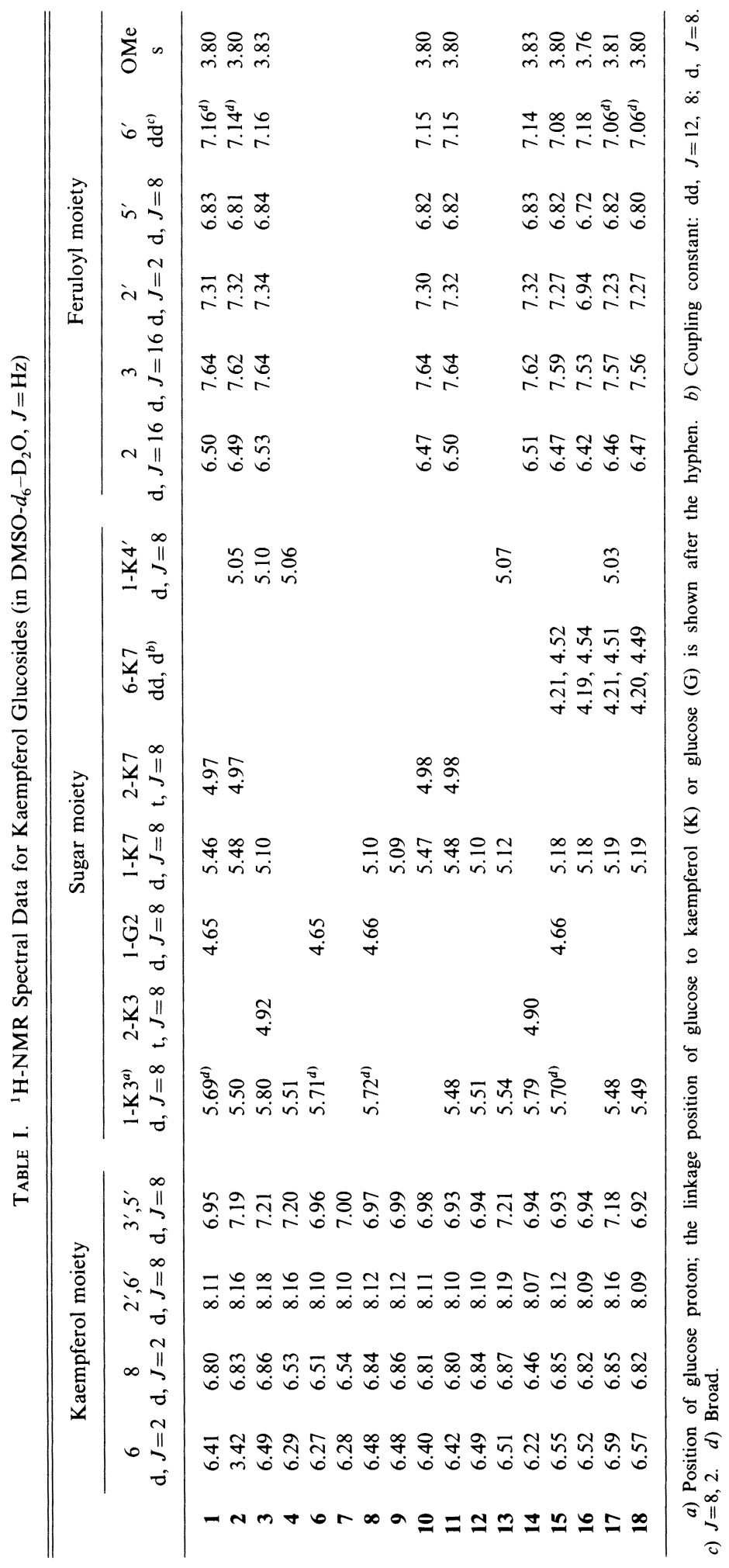




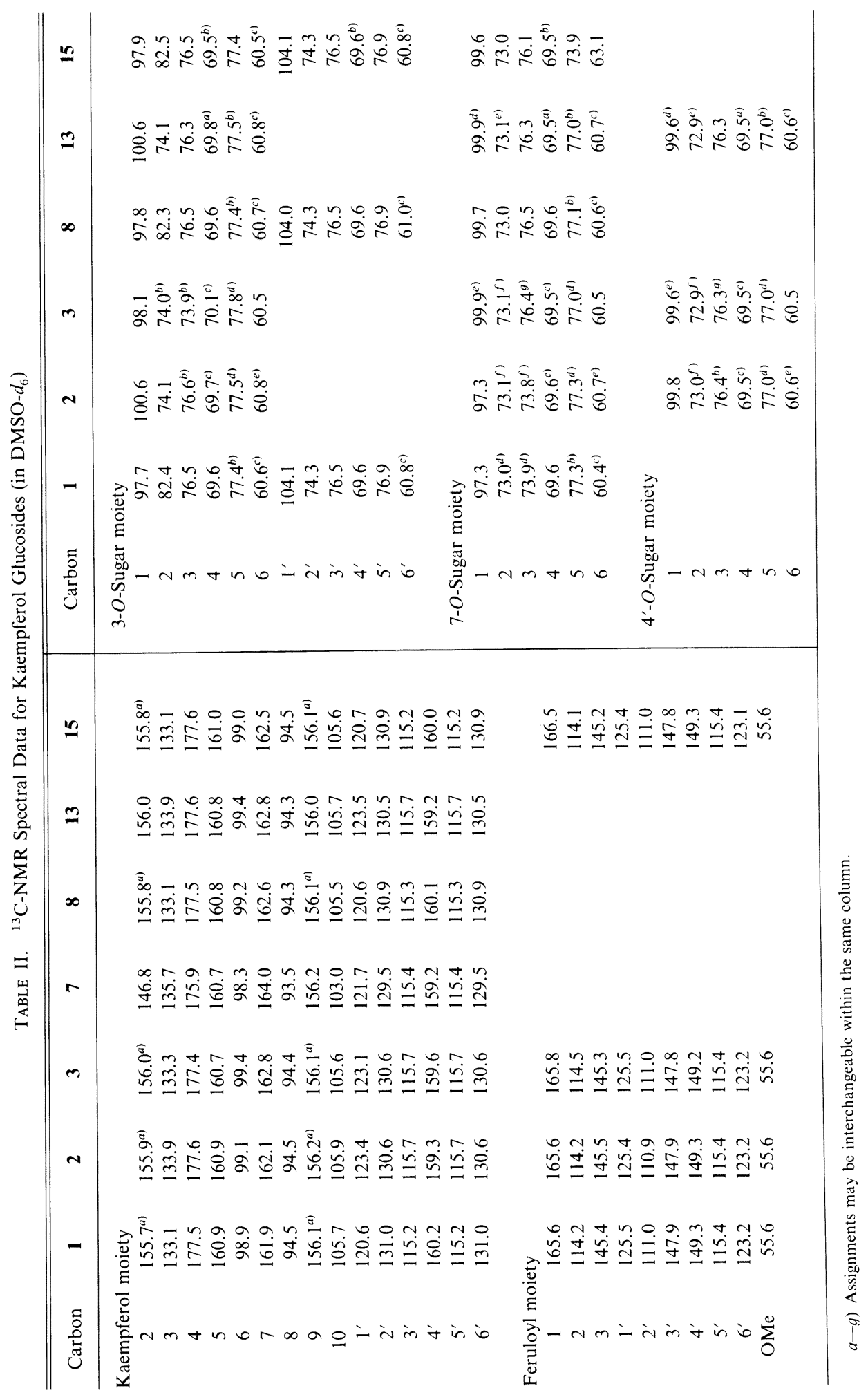


and ${ }^{13} \mathrm{C}-\mathrm{NMR}$ spectra. The ${ }^{1} \mathrm{H}-\mathrm{NMR}$ spectrum of $\mathbf{1}$ exhibited signals ascribable to kaempferol and feruloyl moieties, along with those of three $\beta$-anomeric protons of glucose linked to $C-2^{\prime \prime},-7$ and -3 at $4.65,5.46$ and $5.69 \mathrm{ppm}$, respectively, and a triplet signal due to a proton on carbon bearing an acyl group at $4.97 \mathrm{ppm}$. This triplet signal was found to be coupled with $\mathrm{H}-1^{\prime \prime \prime}$ by spin decoupling. The acylation shifts ${ }^{7.9)}$ in ${ }^{13} \mathrm{C}-\mathrm{NMR}$ spectroscopy are useful for determining the positions of acyl groups in partially acylated glycosides. In the ${ }^{13} \mathrm{C}$ NMR spectrum of 1 , the signals due to $\mathrm{C}-1^{\prime \prime \prime}$ and $-3^{\prime \prime \prime}$ were shifted upfield in comparison with those of $\mathbf{8}$, while other signals remained almost unaffected. These data suggested that the feruloyl group was linked to $\mathrm{C}-2^{\prime \prime \prime}$. In order to confirm this assumption, partial and enzymatic hydrolyses of 1 were examined.

On partial acid hydrolysis with 5\% sulfuric acid, 1 afforded kaempferol glucoside (10). On hydrolysis with $1 \%$ potassium hydroxide, $\mathbf{1 0}$ gave ferulic acid and $\mathbf{9}$. Acetylation of $\mathbf{1 0}$ gave a heptaacetate, the ${ }^{1} \mathrm{H}-\mathrm{NMR}$ spectrum of which showed the signals of four aromatic and three aliphatic acetoxyl protons. The ${ }^{1} \mathrm{H}-\mathrm{NMR}$ spectrum of $\mathbf{1 0}$ exhibited the signal of a $\beta$ anomeric proton of glucose attached to $\mathrm{C}-7$ at $5.47 \mathrm{ppm}$ and a triplet due to a proton on carbon bearing an acyl group at $4.98 \mathrm{ppm}$, coupled with each other. Consequently, 10 was established to be 7-O- $\beta$-D-(2-O-feruloyl)glucosylkaempferol.

On enzymatic hydrolysis with crude hesperidinase, 1 afforded kaempferol glucoside (11). Treatment of $\mathbf{1 1}$ with $1 \%$ potassium hydroxide gave ferulic acid and 3,7-di- $O-\beta$-Dglucosylkaempferol (12), which was identified on the basis of the diagnostic shifts ${ }^{6}$ in the UV spectrum, and the ${ }^{1} \mathrm{H}-\mathrm{NMR}$ spectrum. Acetylation of $\mathbf{1 1}$ afforded a decaacetate, the ${ }^{1} \mathrm{H}-\mathrm{NMR}$ spectrum of which showed the signals of three aromatic and seven aliphatic acetoxyl protons. The ${ }^{1} \mathrm{H}-\mathrm{NMR}$ spectrum of 11 exhibited the signals of two $\beta$-anomeric protons and a triplet due to a proton on carbon bearing an acyl group. Therefore, 11 was established to be $3-O-\beta-\mathrm{D}-$ glucosyl-7- $O-\beta$-D-(2- $O$-feruloyl)glucosylkaempferol.

On the basis of the above results, the structure of compound 1 was established as 3-O- $\beta$ sophorosyl-7- $O-\beta$-D-(2- $O$-feruloyl)glucosylkaempferol.

Compounds $\mathbf{2}$ and 3 exhibited similar absorption maxima in the UV spectrum, and their FD-MS showed $\left[\mathrm{M}^{+}+1\right]$ at $m / z$ 949. On acetylation $\mathbf{2}$ and $\mathbf{3}$ afforded a tridecaacetate, whose ${ }^{1} \mathrm{H}-\mathrm{NMR}$ spectra showed the signals of two aromatic and eleven aliphatic acetoxyl protons. Acid hydrolysis of $\mathbf{2}$ and $\mathbf{3}$ gave kaempferol and D-glucose, and alkaline hydrolysis afforded ferulic acid and kaempferol glucoside (13). These observations indicated that $\mathbf{2}$ and $\mathbf{3}$ are isomers in which the positions of the feruloyl group on 13 differ.

Enzymatic hydrolysis of $\mathbf{1 3}$ with $\beta$-glucosidase gave kaempferol. In the ${ }^{1} \mathrm{H}-\mathrm{NMR}$ spectrum of 13 , the signals of three $\beta$-anomeric protons of glucose linked to phenolic oxygen were observed at $5.07,5.12$ and $5.54 \mathrm{ppm}$, the $\mathrm{H}-3^{\prime}$ and $-5^{\prime}$ signals were shifted downfield in comparison with those of $\mathbf{8}$, and a hydrogen-bonded $5-\mathrm{OH}$ proton signal was observed at $12.61 \mathrm{ppm}$ in dimethyl sulfoxide- $d_{6}\left(\mathrm{DMSO}-d_{6}\right)$. In the ${ }^{13} \mathrm{C}-\mathrm{NMR}$ spectrum, the C-1' signal was shifted upfield ${ }^{7)}$ from that of $\mathbf{8}$. From these results and the diagnostic shifts in the UV spectrum, 13 was established to be 3,7,4'-tri- $O-\beta$-D-glucosylkaempferol, a rare flavonol glycoside that has been isolated only as the $p$-coumarate from Crambe cordifolia. ${ }^{10)}$

The ${ }^{1} \mathrm{H}$-NMR spectrum of $\mathbf{2}$ showed the signals of $\beta$-anomeric protons at 5.05, 5.48 and $5.50 \mathrm{ppm}$, and a triplet due to a proton on carbon bearing an acyl group at $4.97 \mathrm{ppm}$, coupled with the anomeric proton at $5.48 \mathrm{ppm}$. In the ${ }^{13} \mathrm{C}-\mathrm{NMR}$ spectrum of 2 , the signals due to $\mathrm{C}-1$ and -3 of glucose linked to $\mathrm{C}-7$ or $-4^{\prime}$ were shifted upfield compared with those of 13 . Moreover, partial acid hydrolysis of $\mathbf{2}$ afforded $\mathbf{5}$. These data suggested that a feruloyl group is linked to C- $2^{\prime \prime \prime}$. Thus, compound 2 was deduced to be $3,4^{\prime}-\mathrm{di}-O-\beta-\mathrm{D}-\mathrm{glucosyl}-7-O-\beta-\mathrm{D}-(2-$ $O$-feruloyl)glucosylkaempferol.

The ${ }^{1} \mathrm{H}-\mathrm{NMR}$ spectrum of 3 exhibited three $\beta$-anomeric signals, and a triplet due to a proton on carbon bearing an acyl group, coupled with the $\mathrm{H}-1$ " proton. In the ${ }^{13} \mathrm{C}-\mathrm{NMR}$ 
spectrum, the signals due to $\mathrm{C}-1^{\prime \prime}$ and $-3^{\prime \prime}$ were shifted upfield in comparison with those of $\mathbf{1 3}$, while other signals remained almost unaffected.

Enzymatic hydrolysis of 3 with $\beta$-glucosidase yielded kaempferol glucoside (14), and its FD-MS showed $\left[\mathrm{M}^{+}+1\right]$ at $m / z$ 625. Acetylation of 14 afforded a heptaacetate, the ${ }^{1} \mathrm{H}-\mathrm{NMR}$ spectrum of which exhibited the signals of four aromatic and three aliphatic acetoxyl protons. These results showed the elimination of two glucose molecules from 3. The ${ }^{1} \mathrm{H}-\mathrm{NMR}$ spectrum of 14 exhibited the signal of a $\beta$-anomeric proton of glucose attached to C-3 at $5.79 \mathrm{ppm}$, coupled with the triplet signal at $4.90 \mathrm{ppm}$. In this way, $\mathbf{1 4}$ was deduced to be $3-O-\beta$ D-(2-O-feruloyl)glucosylkaempferol.

The above results established compound 3 as $3-O-\beta$-D-(2- $O$-feruloyl)glucosyl-7,4'-di- $O$ $\beta$-D-glucosylkaempferol.

Compound 4 exhibited absorption maxima at 267 and $344 \mathrm{~nm}$ in the UV spectrum, and its FD-MS showed $\left[\mathrm{M}^{+}+1\right]$ at $m / z$ 611. Acid hydrolysis of 3 afforded kaempferol and Dglucose. In the ${ }^{1} \mathrm{H}-\mathrm{NMR}$ spectrum two $\beta$-anomeric proton signals were observed at 5.06 and $5.51 \mathrm{ppm}$, and the signals due to $\mathrm{H}-3^{\prime}$ and $-5^{\prime}$ were shifted downfield in comparison with those of 7. From these data and the diagnostic shifts in the UV spectrum, glucose is linked to C-3 and $-4^{\prime}$. Compound 4 was thus established to be 3,4'-di- $O$ - $\beta$-D-glucosylkaempferol. ${ }^{11}$ )

Compound 5 exhibited absorption maxima at 267 and $348 \mathrm{~nm}$ in the UV spectrum, and its FD-MS showed $\left[\mathrm{M}^{+}+1\right]$ at $m / z$ 627. On acid hydrolysis, 5 afforded quercetin and Dglucose. In the ${ }^{1} \mathrm{H}-\mathrm{NMR}$ spectrum two $\beta$-anomeric proton signals were observed at 4.92 and $5.53 \mathrm{ppm}$, and the signal due to $\mathrm{H}-5^{\prime}$ was shifted downfield from that of quercetin. These data and the diagnostic shifts in the UV spectrum showed that glucose is linked to quercetin at C-3 and $-4^{\prime}$. Consequently, compound 5 was established to be $3,4^{\prime}-\mathrm{di}-O-\beta$-D-glucosylquercetin, which has been isolated from Allium cepa ${ }^{8 a}{ }^{a 12)}$ Allium ascalonicum ${ }^{13)}$ and Ribes species. ${ }^{14)}$

Compound 6 was identified as 3-O- $\beta$-sophorosylkaempferol, which was obtained from 8 by enzymatic hydrolysis with $\beta$-glucosidase.

As compound 1 seemed to be unstable during the process of separation, the stability of 1 was examined. Compound 1 was dissolved in $\mathrm{pH} 3.2,7.0$ and 8.0 buffer solutions and the stability at $100^{\circ} \mathrm{C}$ was checked by high-performance liquid chromatography (HPLC). After

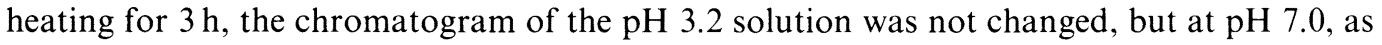
shown in Fig. 1, the peak of 1 at $t_{\mathrm{R}} 7.8$ min disappeared, and peaks a and $\mathrm{b}$ were observed at $t_{\mathrm{R}}$ 3.7 and $11.7 \mathrm{~min}$. At $\mathrm{pH} 8.0$, the peak of $\mathbf{1}$ disappeared and peak a, which was identified as 8 formed by alkaline hydrolysis of $\mathbf{1}$, was recognized.

The product in peak b was obtained as colorless needles (15), whose UV spectrum closely resembled that of 1 . The ${ }^{1} \mathrm{H}-\mathrm{NMR}$ spectrum of its acetate showed the signals of three

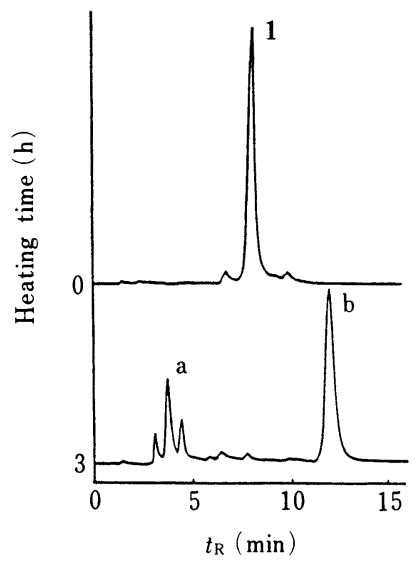

Fig. 1. Chromatogram of $\mathbf{1}$ before and after Heating at $100^{\circ} \mathrm{C}$ at $\mathrm{pH} 7.0$

Column, Nucleosil ${ }_{5} \mathrm{C}_{18}(4.6 \times 250 \mathrm{~mm})$; mobile phase, $\mathrm{MeOH}-\mathrm{H}_{2} \mathrm{O}(45: 55)$; flow rate, $1.0 \mathrm{ml} / \mathrm{min}$; detection, UV $254 \mathrm{~nm}$; oven temperature, $40 \mathrm{C}$. 
aromatic and ten aliphatic acetoxyl protons. On alkaline hydrolysis, $\mathbf{1 5}$ afforded ferulic acid and $\mathbf{8}$. These results indicated that $\mathbf{1 5}$ is an isomer of $\mathbf{1}$ whose feruloyl position on $\mathbf{8}$ differs from that of 1 . In the ${ }^{1} \mathrm{H}-\mathrm{NMR}$ spectrum of 15 , doublet and double doublet proton signals at 4.21 and $4.52 \mathrm{ppm}$ coupled with each other $(J=12 \mathrm{~Hz})$ were observed instead of a triplet signal in the ${ }^{1} \mathrm{H}-\mathrm{NMR}$ spectrum of 1 . In the ${ }^{13} \mathrm{C}-\mathrm{NMR}$ spectrum, the signals due to C-5 and -6 of one of the glucosyl moieties were shifted upfield and downfield, respectively, from those of $\mathbf{8}$. These data suggested that the feruloyl group was linked to C-6 of glucose.

In order to clarify the linkage between the feruloyl and glucose moieties, partial acid hydrolysis of 15 was performed. Hydrolysis of 15 with $5 \%$ sulfuric acid afforded kaempferol glucoside (16). Acetylation of $\mathbf{1 6}$ gave a heptaacetate, the ${ }^{1} \mathrm{H}-\mathrm{NMR}$ spectrum of which showed the signals of four aromatic and three aliphatic acetoxyl protons. On alkaline hydrolysis, 16 yielded ferulic acid and 9 . In the ${ }^{1} \mathrm{H}-\mathrm{NMR}$ spectrum of 16, doublet and double doublet proton signals due to $\mathrm{H}-6^{\prime \prime}$ were observed at 4.19 and $4.54 \mathrm{ppm}$. Compound 16 was thus deduced to be 7-O- $\beta$-D-(6- $O$-feruloyl)glucosylkaempferol.

From the above, 15 was established to be $3-O-\beta$-sophorosyl-7- $O-\beta$-D-(6- $O$-feruloyl)glucosylkaempferol, so that the feruloyl group had migrated from C-2"' to C- 6 "' of the same molecule. Acyl migration in partially acylated carbohydrates is known ${ }^{15}$ under various conditions, especially under mild alkaline conditions. Therefore, 1 was treated with $\mathrm{pH} 11.0$ buffer at room temperature to afford 15 .

A similar acyl migration was observed in 2,10 and 11 — in the case of 10 and 11, only in buffer at $\mathrm{pH} 11.0$, on account of the low solubility of these compounds in $\mathrm{pH} 7.0$ buffer solution-to afford the corresponding 6-O-feruloylates 17,16 and 18 , respectively. The structures of these substances were elucidated by FD-MS, UV spectra and ${ }^{1} \mathrm{H}-\mathrm{NMR}$ spectra.

Six flavonol glycosides were isolated from A. tuberosum, four of them being rare C-4' glycosides. Compounds 1, 2, 3, 10, 11, 14, 15, 16, 17 and 18 are new acylated flavonol glucosides. Compounds 1, 2, 10, 11, 15 and 16 have significant inhibitory effects on the homologous passive cutaneous anaphylaxis reaction in rats at the dose of $2.5 \mathrm{mg} / \mathrm{kg}$ (i.v.). Further biological studies are in progress.

\section{Experimental}

All melting points were determined on a Yanagimoto micromelting point apparatus and are uncorrected. UV spectra were measured on a Hitachi 323 or 228 spectrophotometer. ${ }^{1} \mathrm{H}$ - and ${ }^{13} \mathrm{C}-\mathrm{NMR}$ spectra were taken at 200 and $50.3 \mathrm{MHz}$, respectively, with a Varian XL-200 spectrometer, and chemical shifts are expressed in $\delta$ (ppm) values with tetramethylsilane as an internal standard (s, singlet; $d$, doublet; $t$, triplet; m, multiplet; br, broad). FD-MS were obtained on a JEOL JMS-01SG2 spectrometer. Optical rotation was measured on a Perkin-Elmer 141 or Horiba SEPA 200 polarimeter. GLC was performed on a Hitachi 163 apparatus with a flame ionization detector using a glass column $(3 \mathrm{~mm}$ i.d. $\times 2 \mathrm{~m})$ packed with $3 \%$ OV-225 on Gas Chrom Q $(100-200$ mesh $)$; injection temperature, $280^{\circ} \mathrm{C}$; column temperature, $170^{\circ} \mathrm{C}$; carrier gas, $\mathrm{N}_{2} 55 \mathrm{ml} / \mathrm{min}$. GLC mass spectrometry (GLC-MS) was performed with the chromatographic column coupled to a JEOL JMS D-300 mass spectrometer. HPLC was carried out on a HewlettPackard 1084B apparatus. TLC was performed on Kieselgel $60 \mathrm{~F}_{254}$ (Merck) using the following solvents: (A) EtOAc saturated with $\mathrm{H}_{2} \mathrm{O}$; (B) $\mathrm{BuOH}-\mathrm{AcOH}-\mathrm{H}_{2} \mathrm{O}$ (4:1:5, upper); (C) $\mathrm{BuOH}-$ iso-PrOH- $\mathrm{H}_{2} \mathrm{O}(5: 3: 1)$. The spots were detected by $\mathrm{UV}$ irradiation, $\mathrm{FeCl}_{3}$ reagent or $p$-anisaldehyde- $\mathrm{H}_{2} \mathrm{SO}_{4}$ reagent. D-Glucose was detected by using glucose oxidase (Sigma) followed by bromphenol blue. Acetylation was carried out with acetic anhydride-pyridine in the usual way.

Extraction and Separation-Commercially available fresh leaves of Allium tuberosum RoTTLER (Liliaceae, $59 \mathrm{~kg}$ ) were extracted with $80 \% \mathrm{MeOH}(300 \mathrm{l})$ at room temperature for $12 \mathrm{~d}$, and the extract was concentrated in order to remove $\mathrm{MeOH}$. The residual solution was allowed to stand overnight, and the resulting precipitate was filtered off. The filtrate was passed through a Diaion HP20 (Mitsubishi Chemical Industry Ltd.) column. The column was washed with $\mathrm{H}_{2} \mathrm{O}$ and then eluted with an $\mathrm{H}_{2} \mathrm{O}-\mathrm{MeOH}$ stepwise gradient. The $60 \% \mathrm{MeOH}$ eluate was repeatedly chromatographed on MCI GEL CHP20P (Mitsubishi Chemical Industry Ltd.) with a linear gradient from $40 \%$ $\mathrm{MeOH}$ to $80 \% \mathrm{MeOH}$, and on Sephadex $\mathrm{LH}-20$ with $50 \% \mathrm{MeOH}$ to yield $1(1.04 \mathrm{~g})$ and $2(0.29 \mathrm{~g})$. The $50 \% \mathrm{MeOH}$ eluate was rechromatographed on MCI GEL CHP20P with a linear gradient from $30 \% \mathrm{MeOH}$ to $60 \% \mathrm{MeOH}$ to give 
three fractions (fractions I to III). Fraction III was concentrated to afford $3(0.24 \mathrm{~g})$. Fractions I and II were rechromatographed on Sephadex LH-20 with $50 \% \mathrm{MeOH}$ to yield $4(0.25 \mathrm{~g})$ and $5(0.14 \mathrm{~g})$ from fraction I, and 6 $(0.13 \mathrm{~g})$ from fraction II.

Properties of $1-$ Yellow amorphous powder, mp $212-215^{\circ} \mathrm{C}\left(\mathrm{H}_{2} \mathrm{O}-\mathrm{EtOH}\right) \cdot[\alpha]_{\mathrm{D}}^{22}-84.9^{\circ}(c=1.00$, pyridine $)$. Anal. Calcd for $\mathrm{C}_{43} \mathrm{H}_{48} \mathrm{O}_{24} \cdot \mathrm{H}_{2} \mathrm{O}: \mathrm{C}, 53.42 ; \mathrm{H}, 5.21$. Found: C, 53.27; H, 4.98. FD-MS $m / z: 987\left(\mathrm{M}^{+}+\mathrm{K}\right), 971$ $\left(\mathrm{M}^{+}+\mathrm{Na}\right) . \mathrm{UV} \lambda_{\max }^{\mathrm{EIOH}} \mathrm{nm}(\log \varepsilon): 233$ (4.36), $246(4.27), 269$ (4.31), 333 (4.42). ${ }^{1} \mathrm{H}-\mathrm{NMR}$ : Table I. ${ }^{13} \mathrm{C}-\mathrm{NMR}$ : Table II.

Acetate of $1-$ Colorless amorphous powder, mp $129-130^{\circ} \mathrm{C}(\mathrm{EtOH})$. Anal. Calcd for $\mathrm{C}_{69} \mathrm{H}_{74} \mathrm{O}_{37} \cdot \mathrm{H}_{2} \mathrm{O}: \mathrm{C}$, 54.76; H, 5.06. Found: C, 54.38; H, 4.88. ${ }^{1} \mathrm{H}-\mathrm{NMR}\left(\mathrm{CDCl}_{3}\right) \delta: 1.89-2.10(30 \mathrm{H}$, each s, OAc $\times 10), 2.34,2.36,2.44$ (each $3 \mathrm{H}, \mathrm{s}, \mathrm{Ar}-\mathrm{OAc}), 3.88\left(3 \mathrm{H}, \mathrm{s}, \mathrm{OCH}_{3}\right), 5.82\left(1 \mathrm{H}, \mathrm{d}, J=8 \mathrm{~Hz}, \mathrm{H}-1^{\prime \prime}\right.$ anomeric $), 6.38(1 \mathrm{H}, \mathrm{d}, J=16 \mathrm{~Hz}, \mathrm{CH}=$ C $\underline{H C O}), 6.70(1 \mathrm{H}, \mathrm{d}, J=2 \mathrm{~Hz}, \mathrm{H}-6), 7.00(1 \mathrm{H}, \mathrm{d}, J=2 \mathrm{~Hz}, \mathrm{H}-8), 7.25\left(2 \mathrm{H}, \mathrm{d}, J=8 \mathrm{~Hz}, \mathrm{H}-3^{\prime}, 5^{\prime}\right), 7.73(1 \mathrm{H}, \mathrm{d}, J=16 \mathrm{~Hz}$, $\mathrm{C} \underline{\mathrm{H}}=\mathrm{CHCO}), 8.01\left(2 \mathrm{H}, \mathrm{d}, J=8 \mathrm{~Hz}, \mathrm{H}-2^{\prime}, 6^{\prime}\right)$.

Acid Hydrolysis of 1 - A solution of $1(3 \mathrm{mg})$ in $1 \mathrm{~N} \mathrm{HCl}(1 \mathrm{ml})$ was heated at $100{ }^{\circ} \mathrm{C}$ for $5 \mathrm{~h}$. After cooling, the reaction mixture was extracted with EtOAc. The organic layer was washed with $\mathrm{H}_{2} \mathrm{O}$ and dried over $\mathrm{Na}_{2} \mathrm{SO}_{4}$, then concentrated to dryness to yield a yellow powder, which was identified as kaempferol by comparison with an authentic sample. The aqueous layer was neutralized with Dowex 1-X2 $\left(\mathrm{CO}_{3}^{2-}\right)$ and concentrated to obtain D-glucose which was identified by TLC comparison with an authentic sample.

Alkaline Hydrolysis of 1 -A solution of $1(20 \mathrm{mg})$ in $1 \% \mathrm{KOH}$ was allowed to stand overnight. After acidification with $1 \mathrm{~N} \mathrm{HCl}$, the reaction mixture was extracted with ether. The organic layer was concentrated to dryness and the residue was recrystallized from $\mathrm{H}_{2} \mathrm{O}$ to yield colorless needles $(2 \mathrm{mg})$, which were identified as ferulic acid by comparison with an authentic sample. The aqueous layer was passed through an MCI GEL CHP20P column $\left(\mathrm{pH} 3.0 \mathrm{HCl}\right.$ ), which was washed successively with $\mathrm{pH} 3.0 \mathrm{HCl}$ and $\mathrm{H}_{2} \mathrm{O}$, then eluted with $80 \% \mathrm{MeOH}$. The eluate was concentrated to dryness and the residue was recrystallized from EtOH to yield a pale yellow amorphous powder 8 (13 mg), mp 207-209 ${ }^{\circ} \mathrm{C}$. Anal. Calcd for $\mathrm{C}_{33} \mathrm{H}_{40} \mathrm{O}_{21} \cdot 3 \mathrm{H}_{2} \mathrm{O}: \mathrm{C}, 47.94 ; \mathrm{H}, 5.61$. Found: C, 48.33; H, 5.27. FD-MS $m / z: 811\left(\mathrm{M}^{+}+\mathrm{K}\right), 795\left(\mathrm{M}^{+}+\mathrm{Na}\right) . \mathrm{UV} \lambda_{\max }^{\mathrm{EIOH}} \mathrm{nm}(\log \varepsilon): 267$ (4.42), 349 (4.38); $\lambda^{+\mathrm{NaOAc}}: 267$ (4.42), 351 (4.35); $\lambda^{+\mathrm{NaOMe}}: 276$ (4.41), 395 (4.46); $\lambda^{+\mathrm{AlCl}_{3}}: 275$ (4.41), 302 (4.13), 348 (4.33), 395 (4.21). ${ }^{1} \mathrm{H}-\mathrm{NMR}$ : Table I. ${ }^{13} \mathrm{C}-\mathrm{NMR}$ : Table II.

Partial Acid Hydrolysis of 8 - A solution of $8(30 \mathrm{mg})$ in $1 \% \mathrm{H}_{2} \mathrm{SO}_{4}(2 \mathrm{ml})$ was heated at $100{ }^{\circ} \mathrm{C}$ for $45 \mathrm{~min}$. After cooling, the reaction mixture was extracted with EtOAc. The organic layer was chromatographed on silica gel with EtOAc-EtOH $(1: 1)$ to yield $7-O-\beta$-D-glucosylkaempferol $(9,4 \mathrm{mg})$ as a yellow amorphous powder, which was identified on the basis of diagnostic shifts in the UV spectrum, ${ }^{6}$ and the ${ }^{1} \mathrm{H}-\mathrm{NMR}$ spectrum (Table I). The aqueous layer was neutralized with Dowex 1-X2 $\left(\mathrm{CO}_{3}^{2-}\right)$ and concentrated to obtain sophorose which was identified by TLC comparison with an authentic sample.

Enzymatic Hydrolysis of 8 - A solution of $8(20 \mathrm{mg})$ and $\beta$-glucosidase (20 $\mathrm{mg}$, from almond, Sigma) in pH 5.0 MacIlvaine buffer $(20 \mathrm{ml})$ was incubated at $37^{\circ} \mathrm{C}$ for $5 \mathrm{~h}$. After cooling, the reaction mixture was extracted with $\mathrm{BuOH}$. The organic layer was washed with water and concentrated to dryness to yield 3-O- $\beta$-sophorosylkaempferol $(6,12 \mathrm{mg})$ as a yellow amorphous powder which was identified on the basis of the diagnostic shifts in the UV spectrum, ${ }^{6)}$ and the ${ }^{1} \mathrm{H}-\mathrm{NMR}$ spectrum (Table I).

Methylation Analysis of $1-$ A solution of $1(3 \mathrm{mg})$ and sodium methylsulfinylmethide $(0.5 \mathrm{~mm})$ in DMSO $(0.5 \mathrm{ml})$ was allowed to stand overnight at room temperature. Methyl iodide $(0.1 \mathrm{ml})$ was added and the reaction mixture was stirred at room temperature for $90 \mathrm{~min}$. After dilution with water, the reaction mixture was extracted with $\mathrm{CHCl}_{3}$, and the dried organic layer was concentrated to dryness. The residue was hydrolyzed with $90 \%$ formic acid at $100^{\circ} \mathrm{C}$ for $2 \mathrm{~h}$, and with $0.5 \mathrm{~N} \mathrm{H}_{2} \mathrm{SO}_{4}(1 \mathrm{ml})$ at $100{ }^{\circ} \mathrm{C}$ for $16 \mathrm{~h}$. After neutralization with $\mathrm{BaCO}_{3}$ solution, the reaction mixture was centrifuged and the supernatant was concentrated to dryness. The residue was reduced with $0.5 \%$ sodium borohydride $(0.5 \mathrm{ml})$ at room temperature for $1 \mathrm{~h}$. Boric acid was removed by distillation with $\mathrm{MeOH}$ and the residue was acetylated with acetic anhydride-pyridine $(1: 1,0.5 \mathrm{ml})$ at $100^{\circ} \mathrm{C}$ for $2 \mathrm{~h}$. The reaction mixture was concentrated to dryness and the residue was examined by GLC and GLC-MS, which indicated the presence of 2,3,4,6-tetra- $O$-methyl-1,5- $O$-diacetylglycitol $\left(t_{\mathrm{R}} 7.1 \mathrm{~min}\right)$ and 3,4,6-tri- $O$-methyl-1,2,5- $O$-triacetylglycitol $\left(t_{\mathrm{R}} \quad 12.9\right.$ $\min$ ) in a ratio of $2: 1$.

Partial Acid Hydrolysis of 1 -A solution of $1(50 \mathrm{mg})$ in $5 \% \mathrm{H}_{2} \mathrm{SO}_{4}$ was heated at $100^{\circ} \mathrm{C}$ for $100 \mathrm{~min}$. After cooling, the resulting precipitate was filtered to give a yellow-brown powder, which was recrystallized from EtOH to afford $10(10 \mathrm{mg})$ as a pale yellow amorphous powder, $\mathrm{mp} 215-217^{\circ} \mathrm{C} .[\alpha]_{\mathrm{D}}^{22}+32.0^{\circ}(c=0.20$, pyridine $)$. Anal. Calcd for $\mathrm{C}_{31} \mathrm{H}_{28} \mathrm{O}_{14} \cdot 2 \mathrm{H}_{2} \mathrm{O}: \mathrm{C}, 56.37 ; \mathrm{H}, 4.88$. Found: C, 56.82; H, 4.71. FD-MS $m / z: 625\left(\mathrm{M}^{+}+1\right)$. UV $\lambda_{\max }^{\text {EtOH }} \mathrm{nm}(\log \varepsilon)$ : 235 (4.26), 248 (4.34), 271 (4.26), 330 (4.41), 378 sh (4.28). ${ }^{1} \mathrm{H}-\mathrm{NMR}$ : Table I. Alkaline hydrolysis of 10 afforded ferulic acid and 9 .

Acetate of $10-$ Colorless amorphous powder, mp 131-133 $\mathrm{C}(\mathrm{EtOH})$. Anal. Calcd for $\mathrm{C}_{45} \mathrm{H}_{42} \mathrm{O}_{21} \cdot 1 / 2 \mathrm{H}_{2} \mathrm{O}$ : $\mathrm{C}, 58.25 ; \mathrm{H}, 4.67$. Found: C, 58.21; H, 4.83. ${ }^{1} \mathrm{H}-\mathrm{NMR}\left(\mathrm{CDCl}_{3}\right) \delta: 2.04,2.07,2.08$ (each 3H, s, OAc), 2.31, 2.32, 2.36, 2.42 (each $3 \mathrm{H}, \mathrm{s}, \mathrm{Ar}-\mathrm{OAc}), 3.88\left(3 \mathrm{H}, \mathrm{s}, \mathrm{OCH}_{3}\right), 6.38(1 \mathrm{H}, \mathrm{d}, J=16 \mathrm{~Hz}, \mathrm{CH}=\mathrm{CHCO}), 6.76(1 \mathrm{H}, \mathrm{d}, J=2 \mathrm{~Hz}, \mathrm{H}-6), 7.02$ $(1 \mathrm{H}, \mathrm{d}, J=2 \mathrm{~Hz}, \mathrm{H}-8), 7.37\left(2 \mathrm{H}, \mathrm{d}, J=8 \mathrm{~Hz}, \mathrm{H}-3^{\prime}, 5^{\prime}\right), 7.73(1 \mathrm{H}, \mathrm{d}, J=16 \mathrm{~Hz}, \mathrm{C} \underline{\mathrm{H}}=\mathrm{CHCO}), 7.84(2 \mathrm{H}, \mathrm{d}, J=8 \mathrm{~Hz}, \mathrm{H}-$ $\left.2^{\prime}, 6^{\prime}\right)$.

Enzymatic Hydrolysis of 1-A solution of $1(100 \mathrm{mg})$ and crude hesperidinase (200 mg, Tanabe Seiyaku Co., 
Ltd.) in pH 4.0 MacIlvaine buffer $(25 \mathrm{ml})$ was incubated at $37^{\circ} \mathrm{C}$ for $40 \mathrm{~h}$. After cooling, the resulting precipitate was collected and washed with water to yield $11(61 \mathrm{mg})$ as a yellow amorphous powder, mp $200-205^{\circ} \mathrm{C} .[\alpha]_{\mathrm{D}}^{22}-48.7^{\circ}$ $(c=0.27,0.1 \mathrm{~N} \mathrm{NaOH})$. Anal. Calcd for $\mathrm{C}_{37} \mathrm{H}_{38} \mathrm{O}_{19} \cdot 2 \mathrm{H}_{2} \mathrm{O}: \mathrm{C}, 54.02 ; \mathrm{H}, 5.15$. Found: C, 53.77; H, 5.03. FD-MS $m / z$ : $787\left(\mathrm{M}^{+}+1\right)$. UV $\lambda_{\max }^{\mathrm{EIOH}} \mathrm{nm}(\log \varepsilon): 233$ (4.39), $246(4.33), 269$ (4.34), 333 (4.47). ${ }^{1} \mathrm{H}-\mathrm{NMR}$ : Table I. Alkaline hydrolysis of 11 afforded ferulic acid and 3,7-di-O- $\beta$-D-glucosylkaempferol (12). ${ }^{1} \mathrm{H}-\mathrm{NMR}$ : Table I.

Acetate of 11 Colorless amorphous powder, mp $155-157^{\circ} \mathrm{C}(\mathrm{EtOH})$. Anal. Calcd for $\mathrm{C}_{57} \mathrm{H}_{58} \mathrm{O}_{29} \cdot 2 \mathrm{H}_{2} \mathrm{O}: \mathrm{C}$, 55.07; H, 5.03. Found: C, 55.38; H, 4.64. ${ }^{1} \mathrm{H}-\mathrm{NMR}\left(\mathrm{CDCl}_{3}\right) \delta: 1.91,1.99,2.01,2.04,2.08,2.08,2.10($ each $3 \mathrm{H}, \mathrm{s}$, OAc), 2.32, 2.34, 2.43 (each $3 \mathrm{H}, \mathrm{s}, \mathrm{Ar}-\mathrm{OAc}), 3.87\left(3 \mathrm{H}, \mathrm{s}, \mathrm{OCH}_{3}\right), 5.56\left(1 \mathrm{H}, \mathrm{d}, J=8 \mathrm{~Hz}, \mathrm{H}-1^{\prime \prime}\right.$ anomeric), $6.36(1 \mathrm{H}, \mathrm{d}$, $J=16 \mathrm{~Hz}, \mathrm{CH}=\mathrm{CH} C \mathrm{H}), 6.70(1 \mathrm{H}, \mathrm{d}, J=2 \mathrm{~Hz}, \mathrm{H}-6), 7.00(1 \mathrm{H}, \mathrm{d}, J=2 \mathrm{~Hz}, \mathrm{H}-8), 7.23\left(2 \mathrm{H}, \mathrm{d}, J=8 \mathrm{~Hz}, \mathrm{H}-3^{\prime}, 5^{\prime}\right), 7.71$ $(1 \mathrm{H}, \mathrm{d}, J=16 \mathrm{~Hz}, \mathrm{C} \underline{\mathrm{H}}=\mathrm{CHCO}), 8.03\left(2 \mathrm{H}, \mathrm{d}, J=8 \mathrm{~Hz}, \mathrm{H}-2^{\prime}, 6^{\prime}\right)$.

Properties of $2-$ Pale yellow amorphous powder, mp ,214-217 $\mathrm{C}\left(\mathrm{H}_{2} \mathrm{O}-\mathrm{EtOH}\right) .[\alpha]_{\mathrm{D}}^{22}-39.9^{\circ}(c=0.26$, pyridine). Anal. Calcd for $\mathrm{C}_{43} \mathrm{H}_{48} \mathrm{O}_{24} \cdot 2 \mathrm{H}_{2} \mathrm{O}: \mathrm{C}, 52.44 ; \mathrm{H}, 5.32$. Found: C, 52.75; H, 5.52. FD-MS $m / z: 949\left(\mathrm{M}^{+}+1\right)$. $\mathrm{UV} \lambda_{\max }^{\mathrm{EtOH}} \mathrm{nm}(\log \varepsilon): 232$ (4.38), 268 (4.37), 328 (4.47). ${ }^{1} \mathrm{H}-\mathrm{NMR}$ : Table I. ${ }^{13} \mathrm{C}-\mathrm{NMR}$ : Table II. Acid hydrolysis of 2 gave kaempferol and D-glucose, and partial acid hydrolysis afforded $\mathbf{1 0 .}$

Acetate of 2-Colorless needles, mp 201-205 ${ }^{\circ} \mathrm{C}(\mathrm{EtOH})$. Anal. Calcd for $\mathrm{C}_{69} \mathrm{H}_{74} \mathrm{O}_{37} \cdot 1 / 2 \mathrm{H}_{2} \mathrm{O}: \mathrm{C}, 55.09 ; \mathrm{H}$, 5.03. Found: $\mathrm{C}, 54.81 ; \mathrm{H}, 5.56 .{ }^{1} \mathrm{H}-\mathrm{NMR}\left(\mathrm{CDCl}_{3}\right) \delta: 1.90-2.12(33 \mathrm{H}$, each s, OAc $\times 11), 2.34,2.44($ each $3 \mathrm{H}, \mathrm{s}$, $\mathrm{Ar}-\mathrm{OAc}), 3.88\left(3 \mathrm{H}, \mathrm{s}, \mathrm{OCH}_{3}\right), 5.82\left(1 \mathrm{H}, \mathrm{d}, J=8 \mathrm{~Hz}, \mathrm{H}-1^{\prime \prime}\right.$ anomeric), $6.38(1 \mathrm{H}, \mathrm{d}, J=16 \mathrm{~Hz}, \mathrm{CH}=\mathrm{CHCO}), 6.70(1 \mathrm{H}$, $\mathrm{d}, J=2 \mathrm{~Hz}, \mathrm{H}-6), 7.00(1 \mathrm{H}, \mathrm{d}, J=2 \mathrm{~Hz}, \mathrm{H}-8), 7.25\left(2 \mathrm{H}, \mathrm{d}, J=8 \mathrm{~Hz}, \mathrm{H}-3^{\prime}, 5^{\prime}\right), 7.73(1 \mathrm{H}, \mathrm{d}, J=16 \mathrm{~Hz}, \mathrm{C} \underline{\mathrm{H}}=\mathrm{CHCO})$, $8.01\left(2 \mathrm{H}, \mathrm{d}, J=8 \mathrm{~Hz}, \mathrm{H}-2^{\prime}, 6^{\prime}\right)$.

Properties of 3 Colorless amorphous powder, $\mathrm{mp} 235-238^{\circ} \mathrm{C}\left(\mathrm{H}_{2} \mathrm{O}\right)$. $[\alpha]_{\mathrm{D}}^{22}-206^{\circ}(c=0.22$, pyridine $)$. Anal. Calcd for $\mathrm{C}_{43} \mathrm{H}_{48} \mathrm{O}_{24} \cdot 3 \mathrm{H}_{2} \mathrm{O}: \mathrm{C}, 51.50 ; \mathrm{H}, 5.43$. Found: C, 51.64; H, 5.31. FD-MS $m / z: 949\left(\mathrm{M}^{+}+1\right)$. UV $\lambda_{\max }^{\mathrm{EtOH}} \mathrm{nm}$ $(\log \varepsilon): 232$ (4.47), 269 (4.55), 327 (4.66). ${ }^{1} \mathrm{H}-\mathrm{NMR}$ : Table I. ${ }^{13} \mathrm{C}-\mathrm{NMR}$ : Table II. Acid hydrolysis of 3 afforded kaempferol and D-glucose.

Acetate of 3 Colorless amorphous powder, mp $186-188^{\circ} \mathrm{C}(\mathrm{EtOH})$. Anal. Calcd for $\mathrm{C}_{69} \mathrm{H}_{74} \mathrm{O}_{37} \cdot \mathrm{H}_{2} \mathrm{O}: \mathrm{C}$, 54.76; H, 5.06. Found: C, 54.55; H, 4.91. ${ }^{1} \mathrm{H}-\mathrm{NMR}\left(\mathrm{CDCl}_{3}\right) \delta: 1.94-2.14(33 \mathrm{H}$, each s, OAc $\times 11), 2.35,2.43($ each $3 \mathrm{H}, \mathrm{s}, \mathrm{Ar}-\mathrm{OAc}), 3.90\left(3 \mathrm{H}, \mathrm{s}, \mathrm{OCH}_{3}\right), 5.86\left(1 \mathrm{H}, \mathrm{d}, J=8 \mathrm{~Hz}, \mathrm{H}-1^{\prime \prime}\right.$ anomeric $), 6.38(1 \mathrm{H}, \mathrm{d}, J=16 \mathrm{~Hz}, \mathrm{CH}=\mathrm{CHCO})$, $6.69(1 \mathrm{H}, \mathrm{d}, J=2 \mathrm{~Hz}, \mathrm{H}-6), 6.95(1 \mathrm{H}, \mathrm{d}, J=2 \mathrm{~Hz}, \mathrm{H}-8), 7.70(1 \mathrm{H}, \mathrm{d}, J=16 \mathrm{~Hz}, \mathrm{C} \underline{\mathrm{H}}=\mathrm{CHCO}), 8.02(2 \mathrm{H}, \mathrm{d}, J=8 \mathrm{~Hz}, \mathrm{H}-$ $\left.2^{\prime}, 6^{\prime}\right)$.

Alkaline Hydrolysis of 3-A solution of $3(158 \mathrm{mg})$ was hydrolyzed with $1 \% \mathrm{KOH}(30 \mathrm{ml})$ and worked up in the same way as 1 to obtain ferulic acid and $13(61 \mathrm{mg})$ as a pale yellow amorphous powder, mp $210-213^{\circ} \mathrm{C}\left(\mathrm{H}_{2} \mathrm{O}-\right.$ EtOH). $[\alpha]_{D}^{22}-91.0^{\circ}\left(c=0.22\right.$, pyridine). Anal. Calcd for $\mathrm{C}_{33} \mathrm{H}_{48} \mathrm{O}_{21} \cdot 2 \mathrm{H}_{2} \mathrm{O}: \mathrm{C}, 49.01 ; \mathrm{H}, 5.48$. Found: C, 49.41; $\mathrm{H}$, 5.35. FD-MS $m / z: 773\left(\mathrm{M}^{+}+1\right)$. UV $\lambda_{\max }^{\mathrm{EtOH}} \mathrm{nm}(\log \varepsilon): 268$ (4.35), 321 (4.18), 347 (4.18); $\lambda^{+\mathrm{NaOAc}}: 268$ (4.36), 321 (4.21), 347 (4.18); $\lambda^{+\mathrm{NaOMe}}: 287$ (4.35), 391 (3.88); $\lambda^{+\mathrm{AlCl}_{3}}: 278$ (4.30), 338 (4.23), 394 (3.96). ${ }^{1} \mathrm{H}-\mathrm{NMR}$ (DMSO- $\left.d_{6}\right) \delta$ : $12.61(1 \mathrm{H}, \mathrm{s}, 5-\mathrm{OH})$; (DMSO- $\left.d_{6}-\mathrm{D}_{2} \mathrm{O}\right)$ : Table I. ${ }^{13} \mathrm{C}-\mathrm{NMR}$ : Table II. Enzymatic hydrolysis of 13 with $\beta$-glucosidase afforded kaempferol.

Alkaline Hydrolysis of 2 - A solution of $\mathbf{2}$ was hydrolyzed with $1 \% \mathrm{KOH}$ and worked up in the same way as $\mathbf{1}$ to identify ferulic acid and $\mathbf{1 3 .}$

Enzymatic Hydrolysis of 3 -A solution of $3(40 \mathrm{mg})$ and $\beta$-glucosidase $(120 \mathrm{mg})$ in $\mathrm{pH} 5.0$ Macllvaine buffer $(80 \mathrm{ml})$ was incubated at $37^{\circ} \mathrm{C}$ for $3 \mathrm{~d}$. The reaction mixture was extracted with EtOAc and the organic layer was concentrated to yield a brown residue, which was chromatographed on a Sephadex $\mathrm{LH}-20$ column with $\mathrm{MeOH}$ to yield $10(7 \mathrm{mg})$ as pale yellow prisms, mp $183-185^{\circ} \mathrm{C}(\mathrm{EtOH})$. Anal. Calcd for $\mathrm{C}_{31} \mathrm{H}_{28} \mathrm{O}_{14} \cdot 2 \mathrm{H}_{2} \mathrm{O}: \mathrm{C}, 56.37 ; \mathrm{H}, 4.88$. Found: C, 56.17; H, 4.83. FD-MS $m / z: 625\left(\mathrm{M}^{+}+1\right)$. UV $\lambda_{\max }^{\mathrm{EtOH}} \mathrm{nm}(\log \varepsilon): 236(4.32), 268(4.31), 330(4.45) .{ }^{1} \mathrm{H}-$ NMR: Table I.

Properties of 4 Pale yellow amorphous powder, mp 207-210 ${ }^{\circ} \mathrm{C}$. Anal. Calcd for $\mathrm{C}_{27} \mathrm{H}_{30} \mathrm{O}_{16} \cdot \mathrm{H}_{2} \mathrm{O}: \mathrm{C}, 51.60$; H, 5.13. Found: C, 51.37; H, 5.13. FD-MS $m / z: 611\left(\mathrm{M}^{+}+1\right)$. UV $\hat{\lambda}_{\max }^{\mathrm{MeOH}} \mathrm{nm}(\log \varepsilon): 267(4.39), 344(4.19) ; \lambda^{+\mathrm{NaOAc}}$ : 276 (4.54), 371 (4.11); $\lambda^{+\mathrm{NaOMe}}: 276$ (4.51), 372 (4.14); $\lambda^{+\mathrm{AlCl}_{3}}: 276$ (4.35), 302 (4.17), 343 (4.24), 393 (4.10). ${ }^{1} \mathrm{H}-\mathrm{NMR}$ : Table I. Acid hydrolysis of $\mathbf{4}$ afforded kaempferol and D-glucose.

Properties of $5-$ Yellow amorphous powder, mp 208-212 ${ }^{\circ} \mathrm{C}$. Anal. Calcd for $\mathrm{C}_{27} \mathrm{H}_{30} \mathrm{O}_{17} \cdot \mathrm{H}_{2} \mathrm{O}: \mathrm{C}, 50.32 ; \mathrm{H}$, 5.00. Found: C, 50.26; H, 4.86. FD-MS $m / z: 627\left(\mathrm{M}^{+}+1\right)$. UV $\lambda_{\max }^{\mathrm{EtOH}} \mathrm{nm}(\log \varepsilon): 268(4.31), 349(4.24) ; \lambda^{+\mathrm{NaOAc}}: 276$ (4.45), 323 (4.13) 366 (4.16); $\lambda^{+\mathrm{NaOMe}}: 275$ (4.46), 382 (4.14); $\lambda^{+\mathrm{AlCl}_{3}}: 277$ (4.34), 298 (4.10), 351 (4.18), 396 (4.13);

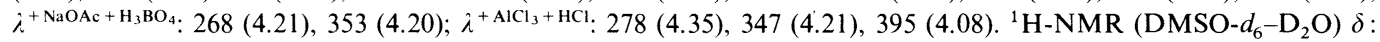
$4.92\left(1 \mathrm{H}, \mathrm{d}, J=8 \mathrm{~Hz}, \mathrm{H}-\mathrm{l}^{\prime \prime \prime}\right.$ anomeric), $5.53\left(1 \mathrm{H}, \mathrm{d}, J=8 \mathrm{~Hz}, \mathrm{H}-\mathrm{l}^{\prime \prime}\right.$ anomeric), $6.25(1 \mathrm{H}, \mathrm{d}, J=2 \mathrm{~Hz}, \mathrm{H}-6), 6.49(1 \mathrm{H}$, $\mathrm{d}, J=2 \mathrm{~Hz}, \mathrm{H}-8), 7.25\left(1 \mathrm{H}, \mathrm{d}, J=8 \mathrm{~Hz}, \mathrm{H}-5^{\prime}\right), 7.65\left(1 \mathrm{H}, \mathrm{brdd}, J=8,2 \mathrm{~Hz}, \mathrm{H}-6^{\prime}\right), 7.68\left(1 \mathrm{H}, \mathrm{d}, J=2 \mathrm{~Hz}, \mathrm{H}-2^{\prime}\right)$. Acid hydrolysis of 5 afforded quercetin and D-glucose.

Properties of $6-$ Yellow needles, mp 195-198 ${ }^{\circ} \mathrm{C}(\mathrm{EtOH})$. Anal. Calcd for $\mathrm{C}_{27} \mathrm{H}_{30} \mathrm{O}_{16} \cdot 2 \mathrm{H}_{2} \mathrm{O}: \mathrm{C}, 50.16 ; \mathrm{H}$, 5.30. Found: C, 50.50; H, 4.96. FD-MS $m / z: 611\left(\mathrm{M}^{+}+1\right)$. UV $\lambda_{\max }^{\mathrm{EtOH}} \mathrm{nm}(\log \varepsilon): 267(4.38), 350(4.30) ; \lambda^{+\mathrm{NaOAc}}: 275$ (4.33), 300 (4.11), 365 (4.10); $\lambda^{+\mathrm{NaOMe}}: 276$ (4.54), 328 (4.29), 406 (4.52); $\lambda^{\mathrm{AlCl}_{3}}: 277$ (4.38), 304 (4.21), 348 (4.30), 397 (4.26). ${ }^{1} \mathrm{H}-\mathrm{NMR}$ : Table I.

Stability Test of Compound $1-$ A $0.1 \%$ solution of compound 1 at pH 3.2 (0.1 M acetate buffer), pH 7.0 or pH 8.0 ( $0.1 \mathrm{M}$ phosphate buffer) was heated at $100^{\circ} \mathrm{C}$ for $3 \mathrm{~h}$, and the stability of 1 was checked by HPLC. 
Procedures of Acyl Migration-i) A solution of $1 \%$ 2-O-acylated flavonol glucoside in $0.1 \mathrm{M} \mathrm{pH} 7.0$ phosphate buffer was heated at $100^{\circ} \mathrm{C}$ for $3 \mathrm{~h}$, and allowed to stand overnight at $5^{\circ} \mathrm{C}$. The resulting precipitate was collected by centrifugation and washed with water to afford 6-O-acylated flavonol glucoside.

ii) A solution of $0.1 \%$ 2-O-acylated flavonol glucoside in $0.1 \mathrm{M} \mathrm{pH} 11.0 \mathrm{Na}_{2} \mathrm{HPO}_{4}-\mathrm{NaOH}$ buffer was allowed to stand at room temperature for $3-8 \mathrm{~h}$, and the solution was acidified with $1 \mathrm{~N} \mathrm{HCl}$. The resulting precipitate was collected by centrifugation and washed with water to afford 6-O-acylated flavonol glucoside.

Properties of 15 Compound 15 was obtained from 1 by methods i and ii above. Colorless needles, mp 214$217^{\circ} \mathrm{C}\left(\mathrm{MeOH}-\mathrm{H}_{2} \mathrm{O}\right)$. $[\alpha]_{\mathrm{D}}^{22}-212^{\circ}(c=0.26$, pyridine $)$. Anal. Calcd for $\mathrm{C}_{43} \mathrm{H}_{48} \mathrm{O}_{24} \cdot 2 \mathrm{H}_{2} \mathrm{O}: \mathrm{C}, 52.44 ; \mathrm{H}, 5.32$. Found: C, 52.38; H, 5.09. FD-MS $m / z: 987\left(\mathrm{M}^{+}+\mathrm{K}\right), 971\left(\mathrm{M}^{+}+\mathrm{Na}\right)$. UV $\lambda_{\max }^{\mathrm{E} \text { moH }} \mathrm{nm}(\log \varepsilon): 233$ (4.31), 247 (4.21), 268 (4.22), 333 (4.33). ${ }^{1} \mathrm{H}-\mathrm{NMR}$ : Table I. ${ }^{13} \mathrm{C}-\mathrm{NMR}$ : Table II. Alkaline hydrolysis of 15 afforded ferulic acid and 8.

Acetate of 15-Colorless amorphous powder, mp 129-131 ${ }^{\circ} \mathrm{C}(\mathrm{EtOH})$. Anal. Calcd for $\mathrm{C}_{69} \mathrm{H}_{74} \mathrm{O}_{37} \cdot 2 \mathrm{H}_{2} \mathrm{O}: \mathrm{C}$, 54.12; H, 5.13. Found: C, 53.93; H, 4.64. ${ }^{1} \mathrm{H}-\mathrm{NMR}\left(\mathrm{CDCl}_{3}\right) \delta: 1.90-2.11(30 \mathrm{H}$, each s, OAc $\times 10), 2.34,2.36,2.41$ (each $3 \mathrm{H}, \mathrm{s}, \mathrm{Ar}-\mathrm{OAc}), 3.88\left(3 \mathrm{H}, \mathrm{s}, \mathrm{OCH}_{3}\right), 5.79\left(1 \mathrm{H}, \mathrm{d}, J=8 \mathrm{~Hz}, \mathrm{H}-1^{\prime \prime}\right.$ anomeric $), 6.40(1 \mathrm{H}, \mathrm{d}, J=16 \mathrm{~Hz}, \mathrm{CH}=$ $\mathrm{C} \underline{\mathrm{HCO}}), 6.70(1 \mathrm{H}, \mathrm{d}, J=2 \mathrm{~Hz}, \mathrm{H}-6), 6.98(1 \mathrm{H}, \mathrm{d}, J=2 \mathrm{~Hz}, \mathrm{H}-8), 7.24\left(2 \mathrm{H}, \mathrm{d}, J=8 \mathrm{~Hz}, \mathrm{H}-3^{\prime}, 5^{\prime}\right), 7.68(1 \mathrm{H}, \mathrm{d}, J=16 \mathrm{~Hz}$, $\mathrm{CH}=\mathrm{CHCO}), 8.02\left(2 \mathrm{H}, \mathrm{d}, J=8 \mathrm{~Hz}, \mathrm{H}-2^{\prime}, 6^{\prime}\right)$.

Partial Acid Hydrolysis of $15-A$ solution of $15(78 \mathrm{mg})$ in $5 \% \mathrm{H}_{2} \mathrm{SO}_{4}-\mathrm{EtOH}(1: 1,20 \mathrm{ml})$ was refluxed for $100 \mathrm{~min}$, then the reaction mixture was concentrated and the resulting precipitate was filtered and recrystallized from EtOH to afford $16(23 \mathrm{mg})$ as yellow needles, $\mathrm{mp} 238-243^{\circ} \mathrm{C}$. $[\alpha]_{\mathrm{D}}^{22}-128^{\circ}(c=0.13, \mathrm{MeOH})$. Anal. Calcd for $\mathrm{C}_{31} \mathrm{H}_{28} \mathrm{O}_{14} \cdot 2 \mathrm{H}_{2} \mathrm{O}: \mathrm{C}, 56.37 ; \mathrm{H}, 4.88$. Found: C, 56.73; H, 4.44. FD-MS $m / z: 625\left(\mathrm{M}^{+}+1\right)$. UV $\lambda_{\max }^{\text {EtOH }} \mathrm{nm}(\log \varepsilon): 235$ (4.35), 247 (4.35), 270 (4.45), 329 (4.57), $376 \mathrm{sh}$ (4.47). ${ }^{1} \mathrm{H}-\mathrm{NMR}$ : Table I. Compound 16 was also obtained from 10 by acyl migration by method ii. Alkaline hydrolysis of $\mathbf{1 6}$ afforded ferulic acid and 9.

Acetate of $16-$ Colorless needles, mp 189-191 ${ }^{\circ} \mathrm{C}(\mathrm{EtOH})$. Anal. Calcd for $\mathrm{C}_{45} \mathrm{H}_{42} \mathrm{O}_{21} \cdot 2 \mathrm{H}_{2} \mathrm{O}: \mathrm{C}, 56.61 ; \mathrm{H}$, 4.86. Found: $\mathrm{C}, 57.06 ; \mathrm{H}, 4.43 .{ }^{1} \mathrm{H}-\mathrm{NMR}\left(\mathrm{CDCl}_{3}\right) \delta: 2.06(3 \mathrm{H}, \mathrm{s}, \mathrm{OAc}), 2.09(6 \mathrm{H}, \mathrm{s}, \mathrm{OAc} \times 2), 2.32,2.34,2.36,2.38$ (each $3 \mathrm{H}, \mathrm{s}, \mathrm{Ar}-\mathrm{OAc}), 3.84\left(3 \mathrm{H}, \mathrm{s}, \mathrm{OCH}_{3}\right), 6.37(1 \mathrm{H}, \mathrm{d}, J=16 \mathrm{~Hz}, \mathrm{CH}=\mathrm{CHCO}), 6.76(1 \mathrm{H}, \mathrm{d}, J=2 \mathrm{~Hz}, \mathrm{H}-6), 7.22(2 \mathrm{H}$, $\left.\mathrm{d}, J=8 \mathrm{~Hz}, \mathrm{H}-3^{\prime}, 5^{\prime}\right), 7.65(1 \mathrm{H}, \mathrm{d}, J=16 \mathrm{~Hz}, \mathrm{CH}=\mathrm{CHCO}), 7.82\left(2 \mathrm{H}, \mathrm{d}, J=8 \mathrm{~Hz}, \mathrm{H}-2^{\prime}, 6^{\prime}\right)$.

Properties of $17-17$ was obtained from 2 by acyl migration by methods i and ii. Pale yellow amorphous powder, mp 233-236 ${ }^{\circ} \mathrm{C}(\mathrm{MeOH}) .[\alpha]_{\mathrm{D}}^{22}-149^{\circ}(c=0.20$, pyridine $)$. Anal. Calcd for $\mathrm{C}_{43} \mathrm{H}_{48} \mathrm{O}_{24} \cdot 4 \mathrm{H}_{2} \mathrm{O}: \mathrm{C}, 50.59 ; \mathrm{H}$, 5.53. Found: C, 50.23; H, 5.09. FD-MS m/z: 949 (M+ $\left.\mathrm{M}^{+}+1\right)$. UV $\lambda_{\max }^{\mathrm{EtOH}} \mathrm{nm}(\log \varepsilon): 232$ (4.59), 243 (4.59), 269 (4.63), 328 (4.71). ${ }^{1} \mathrm{H}-\mathrm{NMR}$ : Table I. ${ }^{13} \mathrm{C}-\mathrm{NMR}$ : Table II.

Acetate of 17-Colorless amorphous powder, mp $179-180^{\circ} \mathrm{C}(\mathrm{EtOH})$. Anal. Calcd for $\mathrm{C}_{69} \mathrm{H}_{74} \mathrm{O}_{37}: \mathrm{C}, 55.40$; $\mathrm{H}, 4.99$. Found: $\mathrm{C}, 55.18 ; \mathrm{H}, 4.93 .{ }^{1} \mathrm{H}-\mathrm{NMR}\left(\mathrm{CDCl}_{3}\right) \delta: 1.90-2.13(33 \mathrm{H}$, each s, OAc $\times 11), 2.36,2.39($ each $3 \mathrm{H}, \mathrm{s}$, $\mathrm{Ar}-\mathrm{OAc}), 3.88\left(3 \mathrm{H}, \mathrm{s}, \mathrm{OCH}_{3}\right), 5.63\left(1 \mathrm{H}, \mathrm{d}, J=8 \mathrm{~Hz}, \mathrm{H}-1^{\prime \prime}\right.$ anomeric $), 6.43(1 \mathrm{H}, \mathrm{d}, J=16 \mathrm{~Hz}, \mathrm{CH}=\mathrm{CHCO}), 6.73(1 \mathrm{H}$, d, $J=2 \mathrm{~Hz}, \mathrm{H}-6), 7.02(1 \mathrm{H}, \mathrm{d}, J=2 \mathrm{~Hz}, \mathrm{H}-8), 7.70(1 \mathrm{H}, \mathrm{d}, J=16 \mathrm{~Hz}, \mathrm{C} \underline{\mathrm{H}}=\mathrm{CHCO}), 8.02\left(2 \mathrm{H}, \mathrm{d}, J=8 \mathrm{~Hz}, \mathrm{H}-2^{\prime}, 6^{\prime}\right)$.

Properties of 18 Compound 18 was obtained from 11 by acyl migration by method i. Colorless amorphous powder, $\mathrm{mp} 253-255^{\circ} \mathrm{C}(\mathrm{EtOH}) .[\alpha]_{\mathrm{D}}^{22}-157^{\circ}\left(c=0.20\right.$, pyridine). Anal. Calcd for $\mathrm{C}_{37} \mathrm{H}_{38} \mathrm{O}_{19} \cdot 4 \mathrm{H}_{2} \mathrm{O}: \mathrm{C}, 51.75 ; \mathrm{H}$, 5.40. Found: C, 51.45; H, 5.40. FD-MS $m / z: 787\left(\mathrm{M}^{+}+1\right)$. UV $\lambda_{\max }^{\mathrm{EtOH}} \mathrm{nm}(\log \varepsilon): 234$ (4.32), 244 (4.34), 267 (4.31), 332 (4.43). ${ }^{1} \mathrm{H}-\mathrm{NMR}$ : Table I.

Acetate of $18-$ Colorless amorphous powder, mp 128-132 ${ }^{\circ} \mathrm{C}(\mathrm{EtOH})$. Anal. Calcd for $\mathrm{C}_{57} \mathrm{H}_{58} \mathrm{O}_{29} \cdot \mathrm{H}_{2} \mathrm{O}: \mathrm{C}$, 54.29; H, 5.12. Found: C, 54.06; H, 4.72. ${ }^{1} \mathrm{H}-\mathrm{NMR}\left(\mathrm{CDCl}_{3}\right) \delta: 1.92,2.00,2.02,2.06,2.08,2.08,2.11($ each $3 \mathrm{H}, \mathrm{s}$, $\mathrm{OAc}), 2.33,2.34,2.38$ (each $3 \mathrm{H}, \mathrm{s}, \mathrm{Ar}-\mathrm{OAc}), 3.86\left(3 \mathrm{H}, \mathrm{s}, \mathrm{OCH}_{3}\right), 5.56\left(1 \mathrm{H}, \mathrm{d}, J=8 \mathrm{~Hz}, \mathrm{H}-1^{\prime \prime}\right.$ anomeric), $6.38(1 \mathrm{H}, \mathrm{d}$, $J=16 \mathrm{~Hz}, \mathrm{CH}=\mathrm{C} \underline{\mathrm{HCO}}), 6.70(1 \mathrm{H}, \mathrm{d}, J=2 \mathrm{~Hz}, \mathrm{H}-6), 6.98(1 \mathrm{H}, \mathrm{d}, J=2 \mathrm{~Hz}, \mathrm{H}-8), 7.66(1 \mathrm{H}, \mathrm{d}, J=16 \mathrm{~Hz}, \mathrm{CH}=$ CHCO), $8.02\left(2 \mathrm{H}, \mathrm{d}, J=8 \mathrm{~Hz}, \mathrm{H}-2^{\prime}, 6^{\prime}\right)$.

\section{References}

1) H. Kameoka and A. Miyake, Nippon Nogeikagaku Kaishi, 48, 385 (1974); A. I. Mackenzie and D. A. Ferns, Phytochemistry, 16, 763 (1977).

2) M. Kaneta, H. Hikichi, S. Endo, and N. Sugiyama, Agric. Biol. Chem., 44, 1405 (1980).

3) Shanghai Science and Technologic Publisher and Shougakukan, "The Dictionary of Chinese Drugs," (中薬大辞典), Vol. I, Shougakukan, Tokyo, 1985, p. 449.

4) S. Hakomori, J. Biochem. (Tokyo), 55, 205 (1964).

5) T. J. Mabry, K. R. Markham, and M. B. Thomas, "The Systematic Identification of Flavonoids," SpringerVerlag, Inc., New York, 1970.

6) N. A. M. Saleh, W. Majak, and G. H. N. Towers, Phytochemistry, 11, 1095 (1972).

7) K. R. Markham, B. Terniai, R. Stanley, H. Geiger, and T. J. Mabry, Tetrahedron, 34, 1389 (1978).

8) a) J. B. Harborn, Phytochemistry, 4, 107 (1965); b) N. A. M. Saleh, ibid., 14, 286 (1975).

9) K. Yamasaki, R. Kasai, Y. Masaki, M. Okihara, O. Tanaka, H. Oshio, S. Takagi, M. Yamaki, K. Masuda, G. Nonaka, M. Tuboi, and I. Nishioka, Tetrahedron Lett., 1977, 1231; H. Ishii, S. Seo, K. Tori, T. Tozyo, and Y. Yoshimura, ibid., 1977, 1227; V. M. Chari, M. Jordan, H. Wagner, and P. W. Thies, Phytochemistry, 16, 1110 (1977). 
10) I. Aguinagalde and M. A. P. Martinez, Phytochemistry, 21, 2875 (1982).

11) N. Ishikura and S. Hayashida, Agric. Biol. Chem., 43, 1923 (1979); W. Henning and K. Harmann; Z. Lebensm. Unters. Forsch., 170, 433 (1980); M. A. P. Martinez and I. Aguinagalde, Parodiana, 1, 287 (1982) [Chem. Abstr., 97, 159508w (1982)]; A. Ulubelen, H. Abdolmaleky, and T. J. Mabry, J. Nat. Prod., 45, 507 (1982); F. Imperato, Chem. Ind. (London), 1983, 204.

12) B. J. Brandwein, J. Food Sci., 30, 680 (1965).

13) L. Bezanger-Beauquesne and A. Delelis, C. R. Acad. Sci., Paris, Ser. D, 265, 2118 (1967) [Chem. Abstr., 68, $75713 x(1968)]$.

14) S. Fred, G. Rudolf, and H. Karl, Z. Lebensm. Unters. Forsch., 179, 315 (1984).

15) L. Brikofer, C. Kaiser, H. Kosmol, G. Romussi, M. Donike, and G. Michelis, Justus Liebigs Ann. Chem., 669, 223 (1966); D. Sato and J. Morita, Chem. Pharm. Bull., 17, 1456 (1969); T. Konishi, A. Tada, J. Shoji, R. Kasai, and O. Tanaka, ibid., 26, 668 (1978); K. Yoshimoto and Y. Tsuda, ibid., 31, 4324 (1983). 